\title{
"Latvia Will Always Be My Home": Latvian Emigrants in Sweden After 1991 in the Latvian National Oral History Collection ${ }^{2}$
}

Wrocławski Rocznik

Historii Mówionej

Rocznik IX, 2019

ISSN 2084-0578

DOI: $10.26774 / \mathrm{wrhm} .254$

Cross-border migration is an important turning point that leads to significant changes in the lives of migrants. Life stories give opportunities to follow this process from the point of view of the social actor. Oral history is used in migration studies researching the inclusion or dissociation of the individual in his or her host country in order to understand the strategies, motivations, and processes that encourage or hinder it.

The National Oral History $(\mathrm{NOH})$ research project at the Institute of Philosophy and Sociology of the University of Latvia aims at documenting the living, unexplored experience of the nation's people in recent historical events. The beginning of the $\mathrm{NOH}$ project dates back to 1992, when it started as a structural unit of the Institute of Philosophy and Sociology. For many years, this study was headed by philosopher Augusts Milts (1928-2008). As M. Zirnite notes: "The project played an important role in Latvia; it made

1 https://orcid.org/oooo-ooo3-1011-3351.

2 The article is based on a wider research project funded by the Latvian Council of Science: Narrative perspectives on intergenerational transmission of memory (project number: lzp-2018/1-0458). 
a claim to the creation of the Latvian memory pool and made the necessary preparations for it. The Latvian Oral History project became a coordination and methodological center that prepared the principles for life story interviewing, and it developed the rules and required documentation for each particular interview."

The collection of the Latvian National Oral History project consists of over 4,70o audio-recorded life stories, several written memoirs, and numerous video recordings. Its archives include interviews with expatriates who immigrated to Sweden after the II World War and with those who emigrated after the restoration of independence in 1991.

One can divide this collection conventionally by the period of entry of the materials. During the early stages of the collection, it was important to document testimonies related to the Soviet-era experience. Much of the information was gathered in fieldworks (similar to folkloristics' expeditions) to cover a wider range of interviewees and document the experiences of people whose life stories might be unknown to the public. This collection has also been supplemented by interviews conducted by various individual authors and organizations, if the significance of these collections or interviews is sufficient for inclusion in the national collection.

The guidelines for collecting Latvian oral history sources were developed in cooperation with Latvian specialists from abroad who conducted seminars and provided professional literature. The Latvian diaspora in other countries became one of the first targets of life-history research expeditions, frequently on the initiative of Latvians living abroad and always with the support, advice, and often with the practical help of local people. ${ }^{4}$

From its inception, the project has involved various foreign researchers and supporters. Those in charge of the project collaborate with Latvian scientists living abroad, public supporters, and the Latvian diaspora, whose life stories have been extensively documented.

3 M. Zirnìte, Dzìvesstāstu pētniecības ekspedīcijas pie latviešiem Norvēgeijā un Zviedrijā, in Kūle, Maija et al. (eds.), LETONIKA. Nacionālā mutvārdu vēsture. Reliğiskās idejas Latvijā (LETONIKA. National Oral History. Religious Ideas in Latvia), Riga 2008, p. 89.

$4 \quad$ Ibidem, p. 90. 
One of the aims of the Latvian National oral history research is interviewing Latvians living in Sweden, who include both the first exile community and more recent Latvian immigrants. "Narrated memories play a special role in the creation of a diaspora. Many crucial characteristics of a diaspora - such as the history of leaving the homeland, memories of home, and a strong group consciousness - are largely created through narration."

At the end of the II World War, roughly 200,00o refugees fled Latvia, approximately 10 percent of the population. About 120,000 of them ended up in Germany's Western occupation zones, while more than 4,0oo refugees fled to Sweden by boat, ${ }^{6}$ trying to escape the re-occupation of Latvia by the Soviet Union.

An important project was carried out from 1996, when many interviews with people who had left Latvia after the II World War as refugees and fled to Sweden on boats were recorded. After several years of interviews, more than sixty life stories were recorded, which eventually resulted in the publication of the book We Didn't Go to Sweden to Become Swedes (Riga, 2010). The book consists of two sections: the academic articles in the first part of the book serve as a watchtower from which one can observe the general outlines of the exile communities in time and space, focusing mainly on identity and community; the life stories in the second part of the book allow the reader to see historical events from the perspective of the actual participants. ${ }^{7}$

With regards to the preservation and transfer of Latvian identity of the Latvian exiles in Sweden, Baiba Bela points to the following essential factors: preservation of the Latvian language; stories and narration in the oral tradition (oral stories help to maintain and pass on Latvian identity); public life; societies, organizations, and festivities; and an anti-Soviet orientation and political reasons. ${ }^{8}$ In the early 1950s, Estonians and Latvians were among the first major immigrant groups to arrive in Sweden. They became well

5 B. Bela, I. Garda-Rozenberga, M. Zirnīe, Migratory memories between Latvia and Sweden, "Oral History, Nordic-Baltic special issue," vol. 44, Autumn 2016, no. 2, p. 72 .

$6 \quad$ Ibidem, p. 69.

$7 \quad$ B. Bela, Latviskās identitātes saglabāšana, tālāknodošana un tās dažādība, in B. Bela (eds.), Mēs nebraucām uz Zviedriju, lai kḷūtu par zviedriem, Riga 2010.

$8 \quad$ Ibidem, pp. 25-33. 
integrated in Sweden, while at the same time they maintained their distinct cultural identity. ${ }^{9}$

In one of their fieldworks in Gotland (Sweden), the oral history researchers received a number of photo negatives by the Swedish photographer David Holmert, who was summoned to the Swedish army in Gotland during the war. Holmert has left a unique photo document of the arrival of Baltic refugees in Gotland, which deals with the boats they used to cross the sea and how Gotland residents took care of the refugees. In 2015, the book Baltic Refugees in Gotland in Photographs by David Holmert: 1944-1945 was published; it consists of photographs by D. Holmert as well as studies on Baltic refugees in Gotland at the end of the II World War. In addition to photographs depicting the refugees' first steps in a foreign country, their everyday lives, and the support of the local residents, the album also includes excerpts from life stories and diaries that have been collected in the Latvian National Oral History Archives. These testimonies, which had been previously unknown to the general public, are about people who crossed the sea in fishing boats to reach Gotland.

There are plans for the publications of several books based on interviews and documentary sources from the Latvian National Oral History collection in the near future: one deals with the organizer of the 1944-1945 refugee boat transport, Valentina Lasmane (1916-2018), and two of the men who steered these boats from Latvia to Sweden, Ëriks Tomsons (born 1918) and Pēteris Jansons (born 1922).

Latvian migration to Sweden continues today. This ongoing wave of immigration to Sweden began after the restoration of Latvian independence in 1991. This emigration seems to be caused and encouraged solely by the decisions of certain individuals. However, at the same time it falls into more significant processes characterized by economic instability in Latvia and the mobility fostered by globalization. In recent years, researchers from the Latvian National Oral History have started a project, which also documents the experiences of new immigrants by conducting life story interviews.

Latvians are one of the most mobile European nations. As Hazans points out, in recent years Latvia has experienced waves of intense emigration, establishing it as one of the European Union member states most affected by this phenomenon. Immediately after Latvia's accession to the EU in 2004,

9 B. Bela, I. Garda-Rozenberga, M. Zirnīte, op. cit., p. 70. 
the United Kingdom, Ireland, and Sweden opened their labor markets to nationals from the new member states, and the outflow from Latvia almost trebled. ${ }^{10}$ Sweden is among the most popular migration destinations from Latvia. ${ }^{11}$ Furthermore, as Hazans points out, 91 percent of Latvia's population aged $18-74^{12}$ has some relative or friend with foreign work experience, and work abroad has become an integral part of Latvian national identity. In the post-crisis period, emigration is "the new normal." ${ }^{13}$

According to the data of the Office of Citizenship and Migration Affairs of Latvia, the number of officially registered Latvian nationals in Sweden continues to grow. On 1 July 2019 they were 4,827 persons, ${ }^{14}$ but that number could be higher because many of Latvians only work in Sweden, and geographical proximity allows them to live in one country and work in another.

There is a large, active diaspora community that is now being explored in this oral history study. Capturing the New Migrants' Life Stories already began in one of the first fieldworks in Sweden, but 2018 saw the start of an enhanced and more extensive analysis of audio recording of the new migration stories. Interviews with emigrants to Sweden carried out within the project supported by NORDPLUS ${ }^{15}$ project activities have been an essential addition to the recent collection.

Interviews with representatives of the new wave of immigrants were obtained from several field studies in Sweden: the first field study took place in Gotland in 2010 (four interviews) and the second across Sweden in 2018

10 M. Hazans, Emigration from Latvia: A Brief History and Driving Forces in the TwentyFirst Century, in R. Kaša, I. Mierina (eds.), The Emigrant Communities of Latvia: National Identity, Transnational Belonging, and Diaspora Politics, SpringerOpen 2019, p. 35, 44 .

11 I. Mieriṇa, I. Koroḷeva, Metodoloǵiskie risinājumi emigrantu viedokḷu izzināšanai pètījumā "Latvijas emigrantu kopienas," in I. Mierin,a (eds.), Latvijas emigrantu kopienas. Cerību diaspora, Riga 2015, pp. 30-31.

12 LETA 2017, Galvenie iemesli iedzìvotāju emigrācijai-zems atalgojums, nespēja atrast darbu in Latvian. Accessed online at http://nra. lv/latvija/221719-galvenie-iemesli-iedzivotaju-emigracijai-zems-atalgojums-nespeja-atrastdarbu.htm (accessed: 1.12.2017).

13 M. Hazans, op. cit., p. 57.

14 https://www.pmlp.gov.lv/lv/assets/PSAV_Aarvalstiis_Latvijas_VPDo1072019.pdf (accessed: 5.11.2019).

15 NORDPLUS Project From Past to Present: Migration and Integration Through the Life Story Network (project number: NPAD-2017-10188). 
(nineteen interviews are currently being conducted). Seventeen women and seven men have been interviewed. Most of the interviewees were born in the 1970s, but some were born in the late 196os or 1980s. One interviewee was born in 1992 and left Latvia as a child at the age of seven, joining her mother's new family in Sweden.

Interviews were conducted by representatives of the diaspora as well as by researchers of oral history from Latvia. The 2018 interviews were conducted by journalist Gunta Neimane, a Latvian who currently lives in Sweden. The photo documentation was made by Petra Ininberga, a secondgeneration Latvian in Sweden whose parents fled to the Scandinavian state at the end of the II World War.

Interviewees are Latvians living in different parts of Sweden: Stockholm, Kramfors, Lulea, Umea, Dorotea, Gothenburg, and Pitea. In addition to interviews, photographic documentation has also been made. One of the results of this study was the creation of the photo exhibition Why Did We Leave? The New Latvians in Sweden (on exhibit from 2018 until the present), which has already been shown in Sweden, Estonia, and several places in Latvia and will continue to travel throughout Latvia. The photos are illustrated with short excerpts from interviews describing both the narrators' motives for leaving and the experience of adapting to a new society, as well as evaluations and reflections on Latvians, Latvianness, and the preservation of national identity in emigration. The narrators were mostly ethnic Latvians, but there are plans to interview the representatives of other ethnic groups.

Although the project is still ongoing, some results have already been achieved for the moment. In general, now there is a collection of life stories that allows us to analyze and compare the different experiences of the two waves of emigration. Despite the fact that these waves differ depending on the reasons for departure, similar topics for research can be found: options and opportunities for integration into the host country and the conditions for facilitating or hindering these processes; loyalty to the country of origin and the host country; and the need to maintain an ethnic identity.

\section{What Does Migration Mean? The Experiences of the Migrants Themselves Life story interviews are an opportunity to share an individual's experience. The life story approach gives the voice to the person, offering an opportu- nity to express his or her interpretation of individual events. The experience of inclusion in the new country is both universal and profoundly personal. This information reveals the motivation to go and the adaptation strategies}


in the new state. It explains the person's own opinions and estimations. As Alessandro Portelli has written: "Oral sources tell us not just what people did, but what they wanted to do, what they believed they were doing, and what they now think they did."

The study identifies the main reasons why people from Latvia choose to make their homes in Sweden: the improvement of living standards; difficulties with living with the prejudices of Latvian society; better education standards; opportunities to receive necessary health services; personal reasons such as family and personal relationships; etc. Respondents point to economic problems as a major reason for leaving Latvia, but as the analysis of life stories reveals, this is not the only reason for emigration. Hence, Zane ${ }^{17}$ points out: "It is not because of the good life that I live here. At home, there was alcohol, swear words, hard work, poverty. That's what my $\mathrm{A}^{* * 18}$ was. Do I want to go back, can I call that a quality life? No! If that's the case, then I choose to live at a distance from my loved ones, from my family." 19

However, later in the interview Zane states that she initially went to Sweden for a training course. She moved to Sweden after graduating from high school in 1997 to explore the world and to gain new experiences. But after having gained experience in a new country and becoming familiar with the education system and job opportunities, the idea to stay there permanently eventually arises:

During the summer, I had to arrange for visas and all the paperwork, so that I could go. It was the first time I went to Riga. I got lost on Briviibas Street. ${ }^{20}$ 'You had never been to Riga and you immediately went to Sweden?' 'Yes. It was the first time I was on an airplane. That was my first time abroad, apart from Estonia. For a rural inhabitant, for a 'country mouse,' I was going somewhere. The only thing I had was courage. No money, no experience. [...] It was like an adventure.

16 A. Portelli, What Makes Oral History Different?, in R. Perks, A. Thomson (eds.), The Oral History Reader, New York 1998, p. 67.

17 The names of the people interviewed have been changed.

18 A small country village in Latvia; the full name is not disclosed due to the data protection of the respondent.

19 Here and below are quotes from life story interviews from the Latvian National Oral History Collection.

20 The main street in Riga. 
In 2000, Zane returned to Sweden with the idea of staying there permanently; she has since established a family with an expatriate from Latvia.

Those who emigrated before 2004 still report prejudice they encountered then (e.g., the stereotype that dancing is synonymous with the sex industry) or the difficulty of equating Latvian higher education with the Swedish system of education. Marija, who moved to Sweden in 1998 because of marriage, remembers:

The beginning was pretty funny, [there were] different situations. Here in Gotland, the attitude to people coming from Eastern Europe used to be extremely prejudiced. [...] I saw a movie that nearly made me cry. People in that movie were all dressed up in some terrible post-war stuff - quilted coats, puffs, felt boots, all looking so impersonal, tasteless. The premises were a real den, but with a bartender in a white blazer, with lace like that. The film was made in the mid-1990s. It was a detective story. Where did they find it at that time? And they judged what we have in Latvia. After that, a terrible movie ${ }^{21}$ suggesting that a good percentage of women in Latvia are prostitutes was filmed. When I talked about dancing in a folk-dance group, they said, 'Oh, you're doing a striptease!' Of course, people get to know you over time. They didn't mean anything rude.

For those who emigrated in later years, such stories do not appear as frequently. Interviews show us that the new immigrants are generally positive about adapting themselves to their new home country. Regarding the feeling of belonging to Sweden, there are contradictory views. They do not feel rejected, but at the same time they have the feeling that "they are not who they used to be," that they are different. In this situation, something positive is also seen. Andris, a businessman now living in Sweden, left Latvia during the economic crisis of 2009, but he admits that the main reason to leave Latvia was because he wanted to try something new in his life. Andris is well integrated into the local community and has made friends among the locals, but he concludes:

21 Buy Bye Beauty, a 2001 documentary film by Swedish director and performance artist Pål Hollender. The film is about the Latvian sex industry and suggests that it is being fueled by businessmen and sex tourists from Sweden visiting Riga. 
I probably don't have a proper sense of belonging [to Sweden]. They are Swedes, and we are Latvians. Among those people who I mingle with, I do not feel a difference. Yes, there is a lack of sense of belonging. [...] They accept you and are friendly. [...] However, whatever relationship we have, there is always a feeling that you are a Latvian and they are Swedes. I am fine all around. I can still go to my neighbor's house, I can go there and drink and sleep, and he will always help me. But I do not feel like a 100 percent Swede.

Today's immigrants also differ from previous migration waves in that they do not break relations with their country of origin but form cross-border links of varying intensity. Their social networks and economic, political, and cultural activities, as well as their life patterns, often involve both countries. ${ }^{22}$

The sense of belonging to two countries simultaneously is characterized in the following quote by Laura, who has been living in Sweden since the early 2ooos. She first came to Sweden for a training course and then married a local man:

It seems to me that I have two homes. When you are here, and you talk about home, you talk about Latvia. When you go to Latvia, and you talk about home, it's about Sweden. I have a family here, but at the same time, everyone - my brother, grandmothers - all are there. Anyway, I am rich and I have two homes.

Iveta Jurkāne-Hobein and Evija Klave call for a look at transnationalism from the point of view of how individuals maintain a link with their countries of origin and their adapted home countries. By using transnational practices, an individual creates his or her own transnational space, in which both the state and the place where the individual currently lives and the country in which the individual was born and had lived before are united. ${ }^{23}$ Nowadays, identity is neither stable nor constant. There is growing talk about plural identities that are contradictory and multifaceted, emerging

22 B. Bela, Starptautiskā migrācija un nacionālā identitāte - transnacionālās piederības veidošanās, in J. Rozenvalds, A. Zobena (eds.), Daudzveidīgās un mainīgās Latvijas identitātes, Riga 2014, p. 296.

23 I. Jurkāne-Hobein, E. Kḷave, Krievvalodīgo latvijiešu Lielbritānijā un Zviedrijā transnacionālā piederība, in I. Mierina (eds.), Latvijas emigrantu kopienas. Cerību diaspora, Riga 2015, pp. 182-183. 
and changing as a result of the intersection of different discourses, practices, and positions. In this sense, migration broadens the field in which identities live and forces us to reconsider our relationships with our homelands. ${ }^{24}$

The life story interviews analyzed in this study reveal that Latvians who emigrated to Sweden after the restoration of Latvia's independence want to be connected to their new home country, but they do not want to lose their ties with Latvia. This is especially true when the children of emigrants reach school age, and the parents are responsible for making a choice for them. They have to decide to what extent the Latvian language and cultural heritage will be integrated in their daily lives. The child will have to make the same decision for him or herself at some later date. The question is about children belonging to a particular environment. The children are torn between two cultures; they also have to make a choice. The transfer of Latvian identity does not take place automatically; it requires effort. Anita first came to Sweden for temporary work in 2005 at the invitation of local Latvian friends. She has stayed in Sweden because she did not feel accepted in Latvia. Now, Anita has two children and is serious about teaching them the Latvian language:

\begin{abstract}
'Why did you think it was crucial for the children to speak Latvian?' 'It seemed important to me, because Latvian is my native tongue. My language is the one in which I can express everything. I can sing, I can cry in it, because we not only speak, but we also cry in our language. [...] The Latvian language is my automatic language, the one in which I want to speak with my children. I could not imagine speaking with my children in English, a language in which I cannot properly talk, might say something incorrectly, and be misunderstood. The Latvian language is a beautiful language.
\end{abstract}

In many of the new emigration stories, the emigres' relationship with their parents in Latvia appears to be one of the essential topics. Is this link the only one that connects them to Latvia? What happens when these links are severed? What do parents in Latvia think about their children's situation? These are the questions we look forward to answering in further studies. Diana has lived in Sweden from 2012, where she moved in the footsteps 
of a Latvian boyfriend who had a better job there than in Latvia. She says:

"I do not want to completely cut my ties to Latvia. We will always have a family in Latvia, and it is our home. I am a little scared that my parents are getting older. Then what? You have to think about helping your parents. This makes me realize that we are so far away."

Analyzing migrants' sense of belonging to different forms of social organizations and geographical locations, I. Koroleva concludes that the sense of belonging of Latvian migrants to their family, kin, and ethnic group is very strong. Although there is often a more negative attitude towards Latvia's institutional forms, the feeling of belonging to Latvia as a physical place and as a birthplace also remains very high. Moreover, content analysis shows that among the emigres who feel a strong attachment to Latvia as a physical place, a large part of them also feel a strong sense of belonging to their host country. ${ }^{25}$

It is noteworthy that one of the recent interviewees has returned to Latvia since being interviewed. The main reason for this, as she has explained, was the desire to reunite with her family in Latvia.

Baiba Bela also points out that there are two different tendencies regarding the preservation of Latvianness and contacts with compatriots: 1 ) isolation from Latvians, integration into the local community, or marginalization; 2) on the contrary, many emigres begin to feel a special need to be Latvian and become involved in various activities of the Latvian community and try to raise their children as Latvians or, in mixed families, give their children the opportunity to understand their Latvian origin. ${ }^{26}$ Latvian social life and communities no longer have such a significant role in the narrative. The interviewed people also participate in various events hosted by Latvian organizations. But for the new wave of emigration, leaving Latvia is not a one-way road. They can plan life differently. There is a desire to continue to maintain the language and culture. It turns out that the things that are understandable in Latvia now require a certain amount of effort. However, one woman, Agnese, indicates that especially when living outside Latvia, she can start to understand what is valuable to her. She first came to Sweden in 2000 to work as a nanny for a friend's family. She later returned to

25 I. Koroleva, The Complex Identities of Latvians Abroad: What Shapes a Migrant's Sense of Belonging?, in R. Kaša, I. Mierina (eds.), The Emigrant Communities of Latvia: National Identity, Transnational Belonging, and Diaspora Politics, SpringerOpen 2019, pp. 74-77.

26 B. Bela, Starptautiskā migrācija..., p. 301. 
study at university, and after graduating stayed in Sweden. She says: "I can only get that true sense of belonging in the Latvian community, together with girls playing 'kokle ${ }^{\prime 27}$ and along with a choir. It's not something about the country, and it's not even about the land; it's something about my roots and where I am from. That is a part of my identity."

Baiba Bela outlines one more topic regarding expatriation: the problematic aspects of Latvia. For exiles, post-Soviet Latvia is sometimes strange and different. The culture created and maintained by people in exile has not developed in the same way as Soviet-era culture in Latvia. Values, norms, beliefs, and life experiences differ. ${ }^{28}$ Narrative analysis leads to the conclusion that the new wave of emigration also points to differences and to what seems unfamiliar or even unacceptable in Latvia. The world is changing very fast. Occasionally, this change happens at the level of values, which is difficult to accept. Although there is no political motive for the new wave of emigration, similar strategies must be used to maintain their identity abroad. The new immigrants acknowledge that because they live away from Latvia, their attitudes and opinions towards different processes have changed. Latvia is also changing. And when talking about what is hindering them from returning to Latvia, it is no longer just about the economic and social security that is missing there. These are other things and feelings the people have become accustomed to in their new home country. As Marija, who moved to Sweden in 1998, points out:

Latvia is changing all the time, and I am changing, too. In the last few years, when I go to Latvia, I cannot deconstruct all those social codes. I feel that. Very often, it is easy to misunderstand something because it [e.g., my notions] does not correspond to the mentality that is common in Latvia now. The language has evolved because it is related to technology, the internet, and other things.

The stories of some new emigrants sound very similar to those of exiled Latvians talking about their feelings when visiting Soviet Latvia. As Vera Pukīte (born 1915) has said: ${ }^{29}$

27 Latvian national musical instrument, like a zither or lute.

28 B. Bela, Latviskās identitātes saglabāšana..., pp. 36-38.

29 Vera Pukite's life story from We Didn't Go to Sweden to Become Swedes, p. 194. 
I feel like I am a foreigner here in Sweden. But in Latvia, everything has changed.

Nothing is like it was before [...] All the trees have grown large. We left in 1944, and now it is 1975; thirty-one years have passed, and since that time the trees have grown, and nature has changed. [...] But here [in Latvia] I am a stranger: a foreign land, a foreign language. [...] I feel like there is no ground under my feet. [...] When I came back, I thought, yes, I was destined to stay here in Sweden.

Oftentimes, the social, political, and economic aspects of inclusion are analyzed. However, several respondents have also noted a new factor that contributes to maintaining a sense of belonging: similarities and closeness related to nature and environment. A close distance to Latvia and a similar environment all help in adapting. One might say that this is a particularly Latvian reason, because Latvians think of themselves as people who are close to nature. This is indicated in a quotation by Marija:

I think my home is here. Nature here reminds me of Kurzeme [a region in Latvia near the Baltic Sea]. I miss my loved ones, my language, and hearing Latvian speech. When I go to Latvia, I always feel some sort of bitterness. But after around two to three days, I want to go back.

Meanwhile, Anita describes her need to enjoy nature and what this feeling means to her in Sweden in an imaginative way: "When we are in nature, I really feel it here; these are Swedish trees. I entered the forest, and I felt that I could not speak with these trees in Latvian, because they did not understand me. When we went by boat along a small river, it completely felt different."

E.V. Bunkše, an American geographer of Latvian descent, points out that the sense of the native landscape plays an important role in the individual's sense of identity, especially in connection with the Latvian sense of poetry and folklore. ${ }^{30}$ Vieda Skultans, a British anthropologist of Latvian origin, recognizes that a sense of landscape is influenced by both its physical experience, the specific biographies of its viewers, and the symbolic frames in which we are used to looking at and talking about landscape. ${ }^{31}$

30 E.V. Bunkše, Latvijas ainavas dzejiskums, "Latvijas Zinātṇu Akadēmijas Vēstis," vol. 66, no. 3, 2012, pp. 6-7.

31 V. Skultans, Narratives of Landscape in Latvian History and Memory, in Empathy and Healing. Essays in Medical and Narrative Anthropology, New York 2007, p. 222. 


\section{Conclusion}

Life story interviews share an individual's experience. The experience of inclusion in the new country is both universal and profoundly personal. This information reveals the motivation to leave and the adaptation strategies in the new country. It explains the person's own opinions and assessments. This is like a message about Latvians who were able to overcome difficulties and successfully begin new lives. Testimonies of the life stories of emigrants reveal strategies of inclusion used by immigrants in their new home countries: the need to learn the language and culture of the new home country; to find a place and community; to define links and relationships with Latvia. The Latvian NOH collection is an essential resource for migration studies.

The story of the new emigration is still ongoing and should continue to be explored. Researchers have an opportunity to capture processes in action. Researchers can return to the informants after some time and ask what their current opinion is and what changes have taken place. The sources of life stories suggest that Latvians who emigrated to Sweden after the restoration of Latvia's independence in general are aware of belonging to Latvia. These links with Latvia and the strength of these links is different. 
Bela B. (eds.), Mēs nebraucām uz Zviedriju, lai kḷutu par zviedriem, Riga 2010.

Bela B., Latviskās identitātes saglabāšana, tālāknodošana un tās dažādība, in Bela B. (eds.), Mès nebraucām uz Zviedriju, lai kḷutu par zviedriem, Riga 2010, pp. 15-44.

Bela B., Starptautiskā migrācija un nacionālā identitāte - transnacionālās piederības veidošanās, in Rozenvalds J., Zobena A. (eds.), Daudzveidīgās un mainīgās Latvijas identitātes, Riga 2014, pp. 296-314.

Bela B., Garda-Rozenberga I., Zirnīte M., Migratory memories between Latvia and Sweden, “Oral History, Nordic-Baltic special issue," vol. 44, Autumn 2016, no. 2, pp. 69-80.

Bunkše E.V., Latvijas ainavas dzejiskums, "Latvijas Zinātṇu Akadēmijas Vēstis," vol. 66, no. 3, 2012, pp. 6-14.

Bystrom M., Frohnert P. (eds.), Reaching a State of Hope: Refugees, Immigrants and the Swedish Welfare State, 1930-200o, Nordic Academic Press 2013.

Hazans M., Emigration from Latvia: A Brief History and Driving Forces in the Twenty-First Century, in Kaša R., Mierina I. (eds.), The Emigrant Communities of Latvia: National Identity, Transnational Belonging, and Diaspora politics, SpringerOpen 2019, pp. 35-68.

Holmert D, Zirnīte M., Lielbārdis A., Baltijas bēgḷi Gotlandē Dāvida Holmerta fotogräfijās: 1944-1945, Riga 2015.

Jurkāne-Hobein I., Kḷave E., Krievvalodīgo latvijiešu Lielbritānijā un Zviedrijā transnacionālā piederība, in Mieriña I. (eds.), Latvijas emigrantu kopienas. Cerību diaspora, Riga 2015, pp. 182183.

Korolyeva I., The Complex Identities of Latvians Abroad: What Shapes a Migrant's Sense of Belonging?, in Kaša R., Mierina I. (eds.), The Emigrant Communities of Latvia: National Identity, Transnational Belonging, and Diaspora Politics, SpringerOpen 2019, pp. 69-95.

Mierina I., Koroḷeva I., Metodoloğiskie risinājumi emigrantu viedokḷu izzināšanai pētījumā "Latvijas emigrantu kopienas," in Mierina I. (eds.), Latvijas emigrantu kopienas. Cerību diaspora, Riga 2015, pp. 26-41.

Portelli A., What Makes Oral History Different?, in Perks R., Thomson A. (eds.), The Oral History Reader, New York 1998, pp. 63-75.

Skultans V., Narratives of Landscape in Latvian History and Memory, in Empathy and Healing. Essays in Medical and Narrative Anthropology, New York 2007, pp. 205-223.

Zirnìte M., Dzìvesstāstu pētniecības ekspedīcijas pie latviešiem Norvēǵijā un Zviedrijā, in Kūle, Maija et al. (eds.), LETONIKA. Nacionālā mutvārdu vēsture. Reliǵiskās idejas Latvijā (LETONIKA. National Oral History. Religious Ideas in Latvia), Riga 2008, pp. 88-103. 
Ginta Elksne

"Latvia Will Always Be My Home": Latvian

Emigrants in Sweden After 1991 in the Latvian National Oral History Collection
Latvians are one of the most mobile European nations. Sweden, which is located relatively close to Latvia, is a popular destination for migrants. Latvian migration to Sweden has a long history. After the II World War, more than 4,ooo people moved from Latvia to Sweden, fleeing Soviet power. The second wave of immigration to Sweden began with the restoration of Latvian independence in 1991 and continues to this day. Both of these waves of migration are documented in the Latvian National Oral History collection that currently consists of over 4,700 audio-recorded life stories. This article analyzes life-story interviews with expatriates in Sweden after the restoration of independence from the NOH collection and explores how the migrants themselves describe their experiences in their new home country, their reflections on Latvians, Latvianness, and the preservation of national identity in emigration. The sources of life stories suggest that Latvians who emigrated to Sweden after the restoration of Latvia's independence in general are aware of belonging to Latvia. To maintain it, they have formed cultural, emotional and physical cross-border bonds of varying types and intensity.

Keywords: oral history, emigration, Latvia, Sweden 